\title{
Tertiarization in Chile: cultural inequality and occupational structure
}

\author{
Modesto Gayo, María Luisa Méndez and Berta Teitelboim
}

ABSTRACT

\begin{abstract}
Tertiarization, or the shift to service economies with an increasing prevalence of non-manual occupations, has been identified as a central phenomenon in contemporary societies. With the purported numerical and political decline of traditional working-class sectors, the middle class has come to be seen in recent decades as the dominant one. This understanding of the way society has evolved has gone along with a growing interest in forms of social differentiation other than the occupational one of industrial societies, including cultural differentiation. This paper briefly reconstructs the debate and shows that while there may have been growth in non-manual occupations, prompting the notion of a progressive shift towards a middle-class society, some important findings make it difficult simply to accept the claim that Chile has become this kind of mesocratic society.
\end{abstract}

María Luisa Méndez is an associate professor at the School of Sociology of Diego Portales University, Santiago, Chile. marialuisa.mendez@udp.cl

Berta Teitelboim is an associate professor at the School of Sociology of Diego Portales University, Santiago, Chile. berta.teitelboim@udp.cl 


\section{I}

\section{Introduction}

The advent of the post-industrial society, foretold since the 1960s by leading intellectuals such as Daniel Bell (1974) and John Galbraith (1967), is considered to have had a number of consequences. The main one is a transformation in the production apparatus of the most advanced societies involving a more or less abrupt transition from an industrial or goods-producing society to a post-industrial or service-producing one. This transition is held to have brought with it another consequence, the reshaping of the social structure. From an eminently working-class society which was dominated by manual work or occupations, and where socialism in politics accordingly played a key role in representing this class's interests, there was a shift to a society in which class membership became less clear-cut as many children of the working class abandoned the living patterns that had characterized it. In other words, the post-industrial society prompted the advent of middle-class society. ${ }^{1}$

The middle class is understood as a variegated grouping of professionals, managers, technicians and administrators (Gayo, 2013a and 2013c) that looks quite different from the membership of the working class. Irrespective of its internal differences (Gayo, Teitelboim and Méndez, 2013), one effect of the emphasis on the importance of this new class was a progressive loss of

$\square$ This study received financial support from the Government of Chile via fondecyt project "Capital cultural y territorio en Chile. La estructuración territorial del espacio social más allá de los capitales" (No. 1130098)

María Luisa Méndez prepared part of this article with support from the CONICYT Centre/FONDAP/15130009.

The authors are also grateful for the considerable assistance provided by Francisca Romero and Sara Correa, both sociologists and research assistants, in the preparation of this study.

1 Within the historical framework of the industrial societies, social classes have usually been conceived and configured on the basis of the occupational structure. More contemporary conceptions of class that have been widely followed in the sociological tradition over the last three decades take the position, in accordance with Marxist thinking, that members of the working class are those working in organizations as non-owners in low-level occupations for which little intellectual training is required, while members of the middle class are likewise employees but are more highly educated and organized (Wright, 1978 and especially 1985), while in another approach generally understood as more Weberian, Erikson and Goldthorpe (1993) can be said to equate the working class with manual, less prestigious occupations, with the middle classes encompassing the whole range from those engaged in non-manual intermediate or routine occupations to the so-called service class, which includes sectors with high social status at the higher service levels. interest in the working class. The growing marginalization of that class, which now fulfilled the same role as Marx had assigned to a property-owning middle class at the outset of capitalism (Marx and Engels, 1971), in that it was first treated as a leading actor in history but then relegated to the status of a residual social category left over from the earlier capitalist regime, was due not only to the success (both socially and in terms of discourse) of the middle class, but to a deeper process: the apparent dissolution of the class structure that had characterized industrial society since its very origins (Pakulski and Waters, 1996; Beck and Beck-Gernsheim, 2002).

Within this broad framework of analysis, the last two decades have seen a sustained revitalization of studies on social stratification in Latin America, and much of this research has concentrated on defining, delimiting and measuring the middle classes (Filgueira, 2001; Atria, Franco and León, 2007; among others). This group of studies has illustrated the growth of middle-class sectors in countries such as Brazil (O'Dougherty, 2002), Chile (León and Martínez, 2004) and Mexico (Torche and López-Calva, 2013), focusing mainly on the shift in the social structure resulting from so-called "tertiarization" or the transition to a service economy. Thus, argument has turned on the burgeoning of the non-manual sector (Filgueira, 2001; Atria, 2004), increased consumption capacity (Knowledge@Wharton, 2008) and rising incomes (Ferreira and others, 2013) and education levels (Daude, 2012). Some studies have also linked the growth of the middle classes to the strengthening of democratic systems (Paramio and Güemes, 2013) ${ }^{2}$ and to economic development (Ferreira and others, 2013). However, there is no consensus as to whether a general shift towards middle-class societies is actually taking place in the Latin America region. Indeed, there is a body of literature that has demonstrated a reluctance to radically accept this phenomenon: notwithstanding the improvements the middle classes may be enjoying, both by their own standards and relative to poorer groups, they are still vulnerable strata that have been unable to

\footnotetext{
2 Paramio and Güemes (2013) note that countries with a large and well-established middle class tend to have sounder democracies, better governance, a stable credit system and higher public-sector health and education spending, the implication being that the middle class plays a fundamental role in economic development and political stability.
} 
consolidate their structural position over time (OECD, 2011; López-Calva and Ortiz-Juárez, 2012; Paramio and Güemes, 2013).

An additional dimension in the global study of the middle classes is the cultural sphere, understood as patterns of cultural participation and taste, with sociological research in this area having been undertaken within an essentially Bourdieusian framework over the last three decades (Bourdieu, 1979). In these studies, the middle class is not just defined by its occupations or its education or income levels, but is characterized as a social group that is culturally active or has a particular propensity towards intense cultural activity (Bennett and others, 2009; Bennett, Bustamente and Frow, 2013; Gerhards, Hans and Mutz, 2013; Roberts, 2004). Some authors argue that this class is active not only in high culture but in mass culture too, which could imply a weakening of symbolic class boundaries as a result of its members' growing adoption of cultural practices usually considered closer to the habits and tastes of lower-class sectors (Peterson and Kern, 1996).

In their attempts at explanation, these studies have generally employed class-based occupational classifications that have repeatedly proved their worth when it comes to understanding cultural inequalities. The present paper, instead of opting for a particular class classification (Gerhards, Hans and Mutz, 2013) based on occupational groupings that draw on other studies from the outset, adopts a Bourdieusian perspective whereby such groupings arise inductively from the analysis of similarities between individuals as derived from their cultural behaviour. In other words, the contribution of this study to the evaluation of the current state of Chilean society necessarily involves an examination of cultural patterns, with occupation coming later as a manifestation of the complex structural ties to which these are subject (Pinto, 2013). Rather than subjecting cultural participation to particular determinants like (occupational) class, a constituent element of this approach is that it opens up the possibility of there being other dividing lines that are as or more important and that might serve to relegate the class interpretation of society to the background.

This study echoes these debates, additionally bringing in, as already mentioned, a dimension crucial to an understanding of the formation of the middle classes in Latin America: cultural tastes and participation practices. The hypothesis is that if tertiarization has become entrenched in Chile, and society there is now dominated by the middle class, there should be patterns of cultural participation that reflect this. What is mainly focused on here is the following. First, the nature of cultural participation profiles and their rough percentage shares are observed in order to gauge the extent and relative weight of different types of cultural activity. Next to be studied is the relationship between this activity and a set of variables that would be expected to influence it, such as education level, socioeconomic group, occupation, age, geographical area and sex. In a middle-class society, a significant erosion of cultural or symbolic class boundaries would be expected, i.e., one would expect to find variables as important as the one that distinguishes people by socioeconomic level and, similarly, by occupation. Once the data are analysed, however, the findings for cultural participation in Chile show a clearly differentiated society with polarization features. To synthesize, on the one hand there is a majority composed of people with low-paid manual and non-manual occupations requiring limited education, while on the other there is a group whose occupations are better paid and usually call for higher levels of education. Considering this, the European or tertiarization model of post-industrialization described for the Latin American case needs to be explored in some depth and not taken for granted as though it would come about through historical momentum. Today's Chile is markedly unequal, and this inequality is manifested in the cultural practices of its citizens, rather producing the impression of a country with serious limitations when it comes to cultural and, by extension, social performance.

To work through these arguments, the present article uses data from the second National Survey on Cultural Participation and Consumption conducted by the National Council for Culture and the Arts ( $\mathrm{CNCA}$ ) in 2009. This study was carried out in Chile's 15 regions among residents aged over 15 , with 4,000 people from this population ultimately being surveyed. The survey questionnaire addressed different subjects, among them: attendance at cultural events, book reading and related activities, ownership of cultural equipment in the home, use of communications media, participation in activities connected with the cultural heritage and active participation in cultural and artistic activities (CNCA, 2011a).

Following this Introduction, the document is structured as follows. Section II deals with research conducted in Chile. Section III discusses the activities studied and the research methods. Section IV investigates cultural inequality in Chilean society. Section V looks at culture, employment and tertiarization. Lastly, section VI gives the conclusions of the study. 


\section{II}

\section{Research in Chile}

In recent years, there has been a burgeoning of Chilean media and academic interest in understanding the country's society as one dominated by the middle class. However, the foundations on which this interpretation has arisen are different from those that allowed these ideas to emerge in more developed countries. First, there has been a progressive emphasis on poverty in the Chilean case. Once it was established that the country had progressed socially and economically and that poverty indices had fallen considerably in quantitative terms, there was a shift (beginning in the late 1990s) towards an interpretation of society that set out from the presence of the middle class, as had been increasingly happening in more advanced countries for several decades. This was important because, in an accelerated intellectual journey, it implied a completely seamless transition, not from working-class industrialization to middle-class post-industrialization, but from poverty to the middle class. ${ }^{3}$ Yet not only does inequality in Chile remain an everyday factor in the structuring of social relationships, but there is ample evidence that social class is still a key variable shaping the behaviour of the country's citizens. ${ }^{4}$

$\mathrm{Be}$ this as it may, it is not only interest in the middle class that has grown (Méndez, 2007 and 2010; Espinoza and Barozet, 2009), as the attention paid to cultural practices has been on the increase as well (Gayo, Teitelboim and Méndez, 2013). Thus, it is considered that the quality of membership in a society should be understood in terms not just of economic success, but also of participation in cultural activities (CNCA, 2011b; Güell, Peters and Morales, 2012), something that has been linked on occasion to human development (UNDP, 2002; Délano, 2011). How has this phenomenon been described in the literature on Chile?

As background, it should be noted that some research into cultural consumption has been done in Chile, but it could hardly be claimed that there has been a profound and wide-ranging debate on the subject so far. There are

\footnotetext{
3 An article by Manuel Canales (2007) reflects on stratification in today's Chilean society, subsequent to the period when poverty was emphasized.

4 A study that acknowledges both inequality and the general increase in wealth among the Chilean population is the one by Rasse, Salcedo and Pardo (2009), who argue for a rethink of inequality and the classifications used to represent it, given the obvious changes undergone by Chilean society in the last 20 years.
}

some studies, most of them recent, whose data are mainly drawn from CNCA surveys, and there is still a long way to go before a body of well-grounded, thoroughgoing and systematic knowledge is established.

It is also important to understand two phenomena associated with recent studies of cultural practices. First, there is a remarkable degree of acceptance of the tertiarization framework for understanding contemporary Chilean society (Brunner, Barrios and Catalán, 1989). The rejection of the class outlook as an explanatory approach, the acceptance that there is a progressive movement towards a middle-class society, the way status is dwelt on as against social class and the recognition of individualization as a key to understanding society are all evidence of this. Again, although this follows on from the previous point, there has been an evident interest in interpreting the Chilean situation from the perspective of research agendas currently fashionable in institutions in the United States and the more developed parts of Europe (Torche, 2007; Nazif, 2007). The knowledge that has been generated on these aspects to date will now be presented, drawing on the main sociological contributions to the study of cultural practices in Chilean society over recent decades. This brief review will bring to light some of the more important patterns identified so far.

First, there is general agreement about a key phenomenon that is considered to have reconfigured Chileans' cultural participation in the past two or three decades. This is the expansion or massification of cultural and non-cultural consumption since at least the early 1980s (Brunner, Barrios and Catalán, 1989; UNDP, 2002; Catalán, 2009). ${ }^{5}$ A study by the Ministry of Social Development shows spending by Chilean households growing substantially in the decade from 1988 to 1997 (Bernasconi and Puentes, 2001). Nonetheless, it is important to realize that massification has been asymmetrical, as Catalán and Sunkel (1990) observed some time ago. These authors argue that two types of mass activity need to be distinguished. First, there are the most massified pastimes, pursued by all social groups and strata (television, music, radio). Then there is another type of massification involving activities that are very

\footnotetext{
5 This article deals with consumption generally and not just that of cultural goods or services.
} 
common but practised to degrees that differ in line with education and income levels. They include reading the press, magazines and books, and cinema-going.

In the second place, notwithstanding the consensus about the growing massification of cultural practices, it is also generally agreed that there are major differences in cultural tastes and participation associated with sociological variables habitually used in analyses of this type (Catalán and Sunkel, 1990; CNCA, 2007; Torche, 2007; Nazif, 2007; Gayo, Teitelboim and Méndez, 2009 and 2013; Güell and Peters, 2012; Gayo, 2013b). They include sex, ${ }^{6}$ occupation or socioeconomic group, region of residence, age, education and status. There is thus full awareness of inequality or inequalities when it comes to cultural consumption or participation. ${ }^{7}$

From a comparative perspective, it has been noted as a third element of analysis that levels of cultural participation are lower in Chile than in many other countries of Latin America. The introduction to a recent CNCA report states: "Cultural consumption is low in Chile... especially by comparison with countries such as Argentina, Uruguay, Colombia, Mexico and Brazil" (CNCA, 2007, p. 6). If participation is higher in the region's main countries, the implication would seem to be that there is something problematic about

\footnotetext{
${ }^{6}$ It is now more common to speak of "gender," but the information routinely gathered refers to the respondent's sex.

${ }^{7}$ As a limitation on such quantitative studies, some authors have argued that a qualitative or more ethnographic approach is required to reach a better understanding of the symbolic distinction or differentiation processes associated with the practice of culture (Aguilar, 2009; Gayo, Teitelboim and Méndez, 2009; Gayo and others, 2011).
}

Chile. In other words, it is felt that there is work to be done to attain levels similar to those of other countries in the region. Yet this could be said even though it is not clear that there is solid evidence for Chile lagging behind in this way (Nivón and Sánchez, 2012; OEI, 2014). Furthermore, the report of the Ministry of Social Development (MIDEPLAN) (Bernasconi and Puentes, 2001) that was cited earlier shows two additional patterns when it comes to international comparison. One is that the proportion of household spending going on culture is similar in Santiago and Montevideo, while in Buenos Aires it is higher. The other is that Buenos Aires has the highest level of spending inequality, while consumption in Montevideo is most egalitarian, with Santiago being in the middle where culture spending is concerned.

In the fourth place, it has been shown that empirical research has been fairly plentiful, whereas theoretical work has been much thinner on the ground. The contribution of Brunner, Barrios and Catalán (1989), although it is now somewhat dated and does not engage much with data on cultural consumption, is perhaps an exception (at least in its explanatory ambition) in a framework of modernization theory with a Bourdieusian cast. Some studies with greater empirical depth (Bernasconi and Puentes, 2001; Nazif, 2007; Torche, 2007; Güell and Peters, 2012) are weaker in their treatment of the theoretical and explanatory dimension. Between these two poles, in terms of the combination of whole society coverage and depth of data analysis, stands the report of the United Nations Development Programme (UNDP), which incorporates qualitative methodologies in a substantive way, thereby constructing a narrative that looks beyond surveys (UNDP, 2002).

\section{III}

\section{Activities studied and research methods}

Studies in Chile have hitherto been characterized by at least three features. First, variables have been categorized in the standard way, i.e., the patterns normally taken for Chile and other countries have been kept to. A clear example of this is the way respondents have been sorted using well-known class categorizations, such as that of Erikson and Goldthorpe (Torche, 2007; Nazif, 2007). The rationale for this proceeding has usually been the needs of comparison, whether or not this actually takes place, with little attention being paid to the fact that the pattern used as the basis for comparison generally comes from studies conducted in a very small group of highly developed countries. The second feature concerns the use of statistical techniques, as preference is given to those that distinguish between independent and dependent variables, with both linear and logistic regressions featuring prominently. The third feature, related to this, is that different cultural tastes and consumption or participation practices have been dealt with separately, which means that it has not been the rule for this dimension of the 
cultural field to be considered holistically, owing to the inclusion of a large set of variables. ${ }^{8}$ A clear example illustrating this is the article by F. Torche (2007) on reading; the same could be said of the chapters of the books edited by Catalán and P. Torche (2005) and Güell and Peters (2012) dealing with cultural consumption.

Processing the data differently, the present study incorporates a very extensive list of cultural activities and preferences that reflects the information available from the National Survey on Cultural Participation and Consumption in Chile conducted in 2009 (see table A1.1 of annex A1). To integrate these variables into a combined analysis, use is made of a statistical technique known as multiple correspondence analysis, which Bourdieu's work, and especially his best-known book, La distinction (1979), was crucial in popularizing, especially in the field of sociology. This technique makes it possible to represent in an n-dimensional space (usually the two most statistically relevant dimensions are chosen) the positions of the respondents as determined by their cultural tastes and behaviour. This allows the relative distances between the latter to be ascertained. Likewise, it can be understood that a set of similar preferences and activities that are fairly close together in the space will represent a differentiated lifestyle. Besides the study of proximity between practices and tastes, multiple correspondence analysis can be used in an attempt to learn what variables might be structuring or influencing the configuration of this particular social space; in other words, what variables might have been contributing to the different lifestyles or cultural participation patterns. Both this and the previous effort are, in principle, limited only by the availability of categorical variables. ${ }^{9}$

Since this study focuses particularly on tertiarization, the occupation variable is especially important. Accordingly, it seemed advisable to keep this variable as disaggregated as possible, since this would allow a renewed discussion of the social structure in modern Chile to be conducted on the basis of a study with a marked inductive component. The idea, ultimately, was to move towards an evaluation of the view of Chile as a tertiarized society, confined, however, to the area of cultural tastes and participation.

When occupation is spoken of, it is important to stress that this does not entail here an attempt to provide

\footnotetext{
8 Articles by Gayo, Teitelboim and Méndez (2009 and 2013) and Gayo (2013b) are exceptions.

${ }^{9}$ Two examples of the use of this statistical technique are Gayo, Savage and Warde (2006) for the United Kingdom and Gayo, Teitelboim and Méndez (2009) for Chile.
}

or construct a system of class like those generally employed in sociology by specialists who have made it their business to study the structure of society. It needs to be made clear that this will be only partially the case. Why partially? Because, to classify respondents, this study sets out (following a common practice) from the International Labour Organization (ILO) International Standard Classification of Occupations (ISCO-88), but with the difference that it tries to leave the classification as disaggregated as possible (see table A2.1 of annex A2). Initially, this meant leaving out all those who had an unregistered occupation or none, usually because they formed part of what has often been called the "passive" population (retirees, students, housewives, etc.). To deal with this, and to avoid using mediated classes, i.e., allocating class in accordance with that of the household head, a classification was produced for those with no occupation, i.e., for people who were unclassified or were repeatedly classified as "passive." To classify them, a distinction was made between the unemployed, students, retirees and housewives, and they were assigned a category reflecting a combination of their level of education and household income, with each variable having four categories. Following this exercise, classification alternatives yielding fewer than 20 cases were grouped under the "other" category and excluded from the analysis. This means that occupation served as a classifying criterion at the outset, but had to be supplemented by other criteria for all the individuals surveyed to have their own class category (see table A2.1 of annex A2), or at least, one that would be intelligible and sociologically substantive from the point of view of understanding the inequalities that are also manifested in occupations (Pinto, 2013).

The purpose of this is to deal with the following problems. First, there is the fact that so-called "informal" work is more prevalent or widespread in Chile than in countries with a higher level of industrial development. Second, the aim was to be in a position to observe what happens within the working and middle classes without setting out from an assumption of internal homogeneity in the former or of a particular heterogeneity, derived especially from the distinction between managerial and professional workers, in the latter. Lastly, it also seemed important, especially considering the changes in families (divorce rates, relationship with and care of older adults, etc.), to include people with no occupation in their own class position, something that was done, as mentioned, on the basis of personal education and household income. 


\section{IV}

\section{Cultural inequality}

Chile has well-defined patterns of cultural participation that are closely linked to structural variables such as occupation, income, education and age. It is vital to appreciate that these patterns are essentially the outcome of the combination of economic and educational capital, which are closely and positively correlated, plus age.

What are these patterns of cultural participation and taste, how many of them are there, and what sociodemographic variables are they associated with? Setting out from a cluster analysis, not presented here for reasons of space, six types of cultural profiles have been identified using the coordinate axes derived from a multiple correspondence analysis. The original map of practices that these coordinates relate to can be seen in figure A2.1, where the relative association between the categories can be studied: the closer together they are, the more likely it is that an individual engages in both practices, always relative to other alternatives. Figure A2.2 explores the variables that could be associated with the axes of this category map or space, highlighting the variables mentioned above: education and socioeconomic levels, and age. Figure A2.3 provides a picture of the average positions in the social space and the relative size of the six cultural profiles referred to, constructed from the coordinates of figure A2.1. By analysing the patterns of cultural activity presented below, we attempt to synthesize the information in figures A2.1, A2.2 and A2.3, as the social and geometric space is the same.

The first pattern encompasses $6.8 \%$ of the sample and is represented by an individual who visits heritage sites, attends lectures, travels abroad, visits museums and the theatre fairly often, goes to the cinema and owns a substantial number of books. This individual is likely to be a young office worker or professional who has studied at university or higher technical level and belongs to socioeconomic group $\mathrm{ABC} 1$ or $\mathrm{C} 2$.

The second pattern, accounting for $9.6 \%$ of the sample, is represented by people who are particular accumulators of cultural items, including collector's editions of books, original paintings, prints and sculptures. Their sociodemographic traits are similar to those of the first pattern, but they may be professionals with a rather longer employment history and thus greater financial security. These two patterns of behaviour may be defined as belonging to the "cultural elite."
The third pattern is qualitatively different from the first two, and its profile is one of mass activity. The main pastimes may include juggling shows, pantomime and magic acts, visits to amusement parks, travel inside Chile, trips to the zoo, communication via the Internet and stadium outings, among other things. This pattern is shared by $8.5 \%$ of respondents, most of them young people with secondary or technical higher education belonging to socioeconomic groups $\mathrm{C} 3$ and above.

The fourth pattern is the working-class version of the previous one, with a greater tendency towards non-participation in the activities named but similar preferences. These include: frequent video or DVD watching, stadium outings, ownership of a reasonable number of books and a taste for rock music. This pattern covers $27.1 \%$ of the sample. This group is also young in the main, although rather less so than the previous one, and belongs to a slightly lower stratum, although its lower bound is also socioeconomic group C3. Its members are mainly employed as drivers, personal service workers, technicians and operators, housewives and the like, have secondary education, and live in households with incomes of at least $\mathrm{Ch} \$ 250,000$ to $\mathrm{Ch} \$ 500,000$ a month. This pattern is somewhat male-dominated.

Lastly, the fifth and sixth patterns are most genuinely representative of the working-class world, or of those catalogued by another study as representatives of cultural inactivity and passivity (Gayo, Teitelboim and Méndez, 2009) from the point of view of participation in culture-related activities that surveys of cultural consumption in Chile have taken an interest in. Passivity is the keynote in the fifth pattern, which accounts for $28.5 \%$ of the sample and is thus the largest of all. Its representatives own few books, preferring religious ones, and their taste in cinema runs to romantic films. From a sociodemographic perspective, they are middle-aged or older people (a majority are women) who have little education and belong to socioeconomic level D or E, dominated by unskilled workers, housewives and retirees with secondary or primary education and household incomes of less than $\mathrm{Ch} \$ 250,000$ a month in both cases. The sixth pattern comprises $19.6 \%$ of respondents and shows a clear profile of inactivity. What stands out, as with the previous group but even more strikingly, is its very limited cultural participation or consumption. Its sociodemographic and occupational features present 
the expected profile: a low educational and economic level, a high degree of ageing, and unskilled work. In general, too, it should be noted that the profiles showing a higher level of cultural activity are usually associated with the Metropolitan Region, while the opposite is true of cultural inactivity or passivity. ${ }^{10}$

To sum up, what can be concluded from this description? Basically, that culturally active behaviour is restricted and diverse. Restricted, first, because at most $50 \%$ of the population engage in it. Excluding the fourth pattern, whose activity is very weak, the figure is no more than $25 \%$, with the most elite pattern, combining the percentages of patterns 1 and 2, standing at around $17 \%$. In other words, the majority of the Chilean population do not participate, or barely participate, in cultural activities, meaning not just the most elite activities but many that are often regarded as mass events. Second, the

\footnotetext{
10 The terms "inactivity" and "passivity" are not at all meant to imply that the behaviour patterns of people thus described are almost devoid of cultural activity in a broad sense. They are descriptions whose main or closest point of reference are the indicators provided by the survey. It may be debated whether the questions are too restrictive in relation to the behaviour types people are ultimately classified by. This study sets great store by the contributions made by survey measurements both in Chile and internationally, especially during the last four decades of studies on cultural behaviour, a tradition to which this research subscribes. Lastly, the use of terms like "passive" or "inactive" is not meant to ascribe responsibility to the individuals thus described. On the contrary, it is intended as an instrument for engaging in a critical dialogue with a social situation that has very probably oppressed them or left them behind.
}

pattern is diverse because there are different participation profiles. Cultural involvement takes various forms whose diversity primarily correlates with people's accumulated economic and educational resources. It could be said that participating or not participating is a function of economic and educational capital, with the pattern indicating that the more such capital has been accumulated, the greater the degree of cultural participation and distinction. Here, it is important to bear in mind that the two types of capital are strongly and positively correlated, which makes it hard to distinguish between them. Thus, economic and cultural resources would appear to explain much of people's propensity to take part in cultural activities generally and certain ones in particular, or to show a preference for particular aesthetic experiences or content. However, an explanation that referred solely to these kinds of capital would necessarily be incomplete, and patterns of cultural consumption in Chile cannot be properly understood without bringing in the age variable (Gayo, Teitelboim and Méndez, 2009). ${ }^{11}$ Tastes and consumption patterns are directly associated with people's age. Table A2.2 presents in dichotomous terms, and for the purpose of simplifying the large amount of information provided above, the structure of the patterns of cultural practice represented by three of the main ones.

\footnotetext{
11 This certainly does not happen only in Chile. Two studies that have also shown the importance of age in the case of the United Kingdom are Bennett and others (2009) and Gayo (2006).
}

\section{$\mathrm{V}$}

\section{Culture, occupation and tertiarization}

The notion of post-industrial or tertiarized society alerted us to a radical shift that was taking place in advanced or more prosperous societies. The old manual worker in his rough clothes was now donning a white collar and working with his mind. Firms were no longer as focused as formerly on producing objects, and serviceoriented businesses were expanding unstoppably. The main ingredients of industry now were no longer natural resources to be processed and the energy sources needed to do this. Now the raw material was the intellect of human resources.

All this was associated with two equally significant phenomena. First, the conditions seemed to be in place for a resounding triumph of individuals' cognitive abilities and intelligence. At last it would be possible to satisfy, even if only in part, one of the great promises of modernity, namely individual achievement, personal success through merit, which would be measured and rewarded, on the whole, in accordance with people's degree of practical intelligence or the productive potential of their knowledge. Consistently with this, a group of people already known as the "middle class" would expand strongly, and its growth suggested the progressive emergence of a society where differences would not be a direct product of the industrial and occupational structure. 
Thus, the framework of employment tertiarization seemed to favour individuals rather than social classes, intelligence and merit rather than ownership of the means of production, social mobility rather than reproduction shaped by family origin, and occupational indifferentiation rather than the obviously hierarchical structures of societies originating in the early stages of industrialization. In other words, tertiarized society could be understood as a more advanced stage of modernity, in which its guiding ideal seemed to have more prospect of being realized.

Is it from this perspective, which came into view 40 years ago, that the behaviour of Chilean society in the early twenty-first century can best be understood? Economically, the answer may be more ambiguous, but in the sphere of cultural practice this is not the model we now have-far from it. Tertiarization in Chile, if it has taken place, has been accompanied by marked cultural inequality, partially analysed in the previous section. The present section will concentrate on the occupational or work dimension, focusing on the findings observed in figure A2.4 of annex 2.

From the point of view of the occupational structure, Chilean society does not seem to have been shaped according to a pattern of integration around a large middle class. This is not to deny that an ever larger number of its members have acquired increasing wealth. Rather, it is to recognize that the prevailing pattern is one of polarization between two major groups of occupations, which would at least partially explain the division between participation and inactivity that characterizes the structure of the social space in the country (Gayo, Teitelboim and Méndez, 2013). In other words, there is a group of occupations comprising professionals in particular, high-level executives, engineering technicians and office workers that is associated collectively with more or less elite versions of cultural participation. On the other hand, those employed as labourers in the primary sector, unskilled workers, drivers, workers in the metal and textile industries, machinery operators, shop assistants and personal service workers form a group characterized chiefly by low cultural participation-two broad occupational categories that it would surely not be difficult to associate with different levels of income and education, with the averages being lower in the second group than in the first. Accordingly, it can be appreciated that Chile has two major occupational groupings or clusters whose experiences are bound up both with their economic circumstances and with highly differentiated aesthetic practices and orientations. Society is not dominated by the middle class, but is strikingly polarized.
Figure A2.4 shows beyond doubt that these groups are not completely homogeneous, as differences can be identified in both occupational blocs (Gayo, Teitelboim and Méndez, 2013). These differences include the following. In the occupational grouping that is less culturally active, those participating least are the least qualified, namely primary-sector labourers and unskilled workers, while more skilled people, including shop assistants and personal service workers, participate more. As regards the more active group, what stands out is that professionals have a more elite profile than high-level executives, showing that education is at least as important as money, certainly when it comes to cultural activity or the accumulation of cultural capital in a broad sense.

But what about the groups so far unmentioned, namely housewives, retirees, students and the unemployed? Research does not normally include these categories, much less to the level of complexity they are developed to in this study, so that little is known in detail about the patterns characterizing them, and this is both effect and cause of the lack of reflection around the subject. The findings of the present research clearly indicate a need to make distinctions within each of these groups. Among the most interesting conclusions that it has been possible to draw are the following:

(i) There is great stratification in all cases. For example, retirees with higher education and monthly household incomes of over $\mathrm{Ch} \$ 1$ million seem to have little in common with those who state they have studied only at the primary level and have monthly incomes of less than $\mathrm{Ch} \$ 250,000$.

(ii) Education seems to be a key variable when it comes to understanding the position in the social space of the class categories analysed here. There are cases where cultural behaviour is clearly participatory even when incomes are moderate. This is true, for instance, of unemployed people with higher education and incomes of between $\mathrm{Ch} \$ 500,000$ and $\mathrm{Ch} \$ 1$ million a month and housewives with higher education and household incomes in the range of $\mathrm{Ch} \$ 250,000$ to $\mathrm{Ch} \$ 500,000$. This seems to indicate that the key to participatory behaviour is education, subject to the conditions determined by the availability of a minimum of financial resources, with the threshold seeming to be a household income of between $\mathrm{Ch} \$ 250,000$ and $\mathrm{Ch} \$ 500,000$ a month.

(iii) The categories with incomes below $\mathrm{Ch} \$ 250,000 \mathrm{a}$ month and secondary education or less seem to form part of the same grouping, comprising occupations associated with a lower level of cultural activity. 


\section{VI}

\section{Conclusions}

This article has presented a critical discussion of the characteristics of the tertiarization process in Chilean society: although there has been an increase in non-manual occupations, suggesting the notion of a progressive movement towards a middle-class society, some major findings make it difficult to simply accept the claim that Chile has turned into this kind of mesocratic society.

In the first place, the expected collapse of cultural or symbolic class boundaries has not occurred. The evidence shows that we are living in societies where, at least as far as culture goes, most citizens could hardly be classified as members of the middle class. If being culturally active is what characterizes this class, a bare $17 \%$ of the sample of respondents really fit the description, and the level of activity drops very substantially in the other types of cultural profile found.

In the second place, the effects of variables that might traditionally be considered in the study of inequality are far from being a thing of the past. In fact, explaining inequality (which becomes manifest in the cultural practices of citizens) requires a large set of these variables to be considered in combination, chief among them education, financial resources and, to a lesser degree, age.

In the third place, and partly as a way of summarizing the contributions of these variables, it is important to stress the key role played by occupational structure. One pattern that goes a long way towards explaining the findings of this study reveals a society polarized around two major occupational blocs, which can be regarded as "homologous"12 or as corresponding to two major patterns of cultural participation. On the one hand, there are people with low-paid jobs requiring little education, examples being the different types of industrial and service workers. This set of occupations evinces very limited cultural participation. On the other, there are jobs that are better paid and usually demand higher levels of education, namely those of high-level executives, technicians of various kinds and, above all, professionals.

Lastly, by way of synthesis, and accepting that Chile has undergone partial tertiarization of its production and occupational structure, a proper understanding of this society requires the following conclusions to be accepted. First, that tertiarization has had a clearly restricted character, with its beneficiaries being above all the higher socioeconomic groups, which enjoy distinctive lifestyles available only to a very limited portion of the population. Second, that the traditional underpinnings of inequality, such as income and education, are still present, and this comes out very strongly in the way people live and behave. And third, that occupations are still key indicators of behaviour patterns, and their cultural profile shows that Chile is a divided society, both economically and culturally.

\footnotetext{
12 In Bourdieu's work, the "homology" thesis means two things. First, if social fields are understood to be structured by a logic of domination, the implication is that individuals will tend to be situated in similar positions in different fields. Second, this thesis also maintains that there is a correspondence between cultural patterns and social structure, i.e., cultural tastes and practices are structured by social variables, especially economic and cultural capital.
} 


\section{Bibliography}

Aguilar, O. (2009), "Principios de diferenciación material y simbólica en la estratificación social", El arte de clasificar a los chilenos. Enfoques sobre los modelos de estratificación en Chile, A. Joignant and P. Güell (coords.), Santiago, Ediciones Universidad Diego Portales.

Allen, J. (1992), "Post-industrialism and post-Fordism", Modernity and Its Futures, S. Hall, D. Held and T. McGrew (eds.), Cambridge, Polity Press/Open University.

Atria, R. (2004), "Estructura ocupacional, estructura social y clases sociales", Políticas Sociales series, No. 96 (LC/L.2192-P), Santiago, Economic Commission for Latin America and the Caribbean (ECLAC)

Atria, R., R. Franco and A. León (coords.) (2007), Estratificación y movilidad social en América Latina. Transformaciones estructurales de un cuarto de siglo, Santiago, LoM Ediciones/Economic Commission for Latin America and the Caribbean (ECLAC).

Beck, U. and E. Beck-Gernsheim (2002), Individualization, London, SAGE.

Bell, D. (1974), The Coming of Post-Industrial Society. A Venture in Social Forecasting, London, Heinemann.

Bennett, T. and others (2009), Culture, Class, Distinction, London, Routledge.

Bennett, T., M. Bustamante and J. Frow (2013), "The Australian space of lifestyles in comparative perspective", Journal of Sociology, vol. 49, No. 2-3, SAGE.

Bernasconi, O. and E. Puentes (2001), Gasto en bienes y servicios culturales de los hogares del Gran Santiago: 1988-1997, Santiago, Ministry of Social Development.

Bottomore, T. and P. Goode (eds.) (1978), Austro-Marxism, Oxford, Clarendon Press

Bourdieu, P. (1979), La distinction, Paris, Les Éditions de Minuit.

Brunner, J.J., A. Barrios and C. Catalán (1989), Chile: transformaciones culturales y modernidad, Santiago, Latin American Faculty of Social Sciences (FLACSO).

Canales, M. (2007), "Ni pobres ni incluidos: ¿nueva cuestión social?", Revista de Sociología, No. 21, Santiago, University of Chile.

Carabaña, J. and A. Francisco (comps.) (1994), Teorías contemporáneas de las clases sociales, Madrid, Editorial Pablo Iglesias.

Catalán, C. (2009), "Consumo y segmentación: algunas consideraciones conceptuales y empíricas", El arte de clasificar a los chilenos. Enfoques sobre los modelos de estratificación en Chile, A. Joignant and P. Güell (coords.), Santiago, Ediciones Diego Portales University.

Catalán, C. and G. Sunkel (1990), "Consumo cultural en Chile: la elite, lo masivo y lo popular", Working Paper, No. 455, Santiago, Latin American Faculty of Social Sciences (FLACSO).

Catalán, C. and P. Torche (2005), Consumo cultural en Chile: miradas y perspectivas, Santiago, National Institute of Statistics/National Council for Culture and the Arts.

CNCA (National Council for Culture and the Arts) (2011a), Segunda Encuesta Nacional de Participación y Consumo Cultural (ENPCC), Valparaíso, Ediciones Cultura.

(2011b), Política cultural 2011-2016, Valparaíso.

(2007), Encuesta de Consumo Cultural 2004-2005, Valparaíso.

Daude, C. (2012), "Educación, clases medias y movilidad social en América Latina", Las clases medias en sociedades desiguales, Pensamiento Iberoamericano, No. 10.

Délano Urrutia, M. (2011), "Las políticas culturales en Chile como motor del desarrollo humano", Políticas culturales: contingencia y desafios, Santiago, Lom Ediciones.

El Mercurio (2009), "Más de la mitad de la población no participa en actividades culturales", Santiago, 8 January.

Erikson, R. and J.H. Goldthorpe (1993), The Constant Flux. A Study of Class Mobility in Industrial Societies, Oxford, Clarendon Press.
Espinoza, V. and E. Barozet (2009), “De qué hablamos cuando decimos "clase media""? Perspectivas sobre el caso chileno", El arte de clasificar a los chilenos. Enfoques sobre los modelos de estratificación en Chile, A. Joignant and P. Güell (coords.), Santiago, Ediciones Universidad Diego Portales.

Ferreira, F. and others (2013), Economic Mobility and the Rise of the Latin American Middle Class, Washington, D.C., World Bank.

Filgueira, C. (2001), "La actualidad de viejas temáticas: sobre los estudios de clase, estratificación y movilidad social en América Latina", Políticas Sociales series, No. 51 (LC/L.1582-P), Santiago, Economic Commission for Latin America and the Caribbean (ECLAC).

Franco, R., M. Hopenhayn and A. León (coords.) (2010), Las clases medias en América Latina, Santiago, Mexico City, Siglo xxI/ Economic Commission for Latin America and the Caribbean (ECLAC).

Galbraith, J.K. (1967), The New Industrial State, Princeton, Princeton University Press.

Gayo, M. (2013a), "Revisiting middle-class politics: a multidimensional approach - evidence from Spain", The Sociological Review, vol. 61 , No. 4, Wiley.

(2013b), "La teoría del capital cultural y la participación de los jóvenes. El caso chileno como ejemplo", Última Década, No. 38, Valparaíso, Centro de Estudios Sociales CIDPA.

(2013c), "El problema de la delimitación o boundary problem. Una aproximación a la definición de la clase media", Polis. Revista Latinoamericana, vol. 12, No. 36.

(2008), “ ¿Sigue vivo el sector de empleo? La fractura entre sectores de empleo y el comportamiento político en la clase de servicio: España, 1989-2003”, Administración y Ciudadanía, vol. 3, No. 2, Escuela Gallega de Administración Pública.

(2006), "Leisure and participation in Britain", Cultural Trends, vol. 15, No. 2-3, Taylor \& Francis.

(2003), "Divisiones de sector de empleo y comportamiento político en la clase de servicio: España, 1989-2000", Revista Internacional de Sociología, vol. 61, No. 35 .

Gayo, M., M. Savage and A. Warde (2006), "A cultural map of the United Kingdom, 2003”, Cultural Trends, 58/59, vol. 15, No. 2-3, Taylor \& Francis.

Gayo, M. and others (2011), "Consumo cultural y desigualdad de clase, género y edad: un estudio comparado en Argentina, Chile y Uruguay", Avances de Investigación series, No. 62, Madrid, Carolina Foundation-CeALCI.

Gayo, M., B. Teitelboim and M.L. Méndez (2013), "Exclusividad y fragmentación: los perfiles culturales de la clase media en Chile", Universum, vol. 1, No. 28, University of Talca.

(2009), "Patrones culturales de uso del tiempo libre en Chile. Una aproximación desde la teoría bourdieuana", Universum, vol. 24 , No. 2, University of Talca.

Gerhards, J., S. Hans and M. Mutz (2013), "Social class and cultural consumption: the impact of modernisation in a comparative European perspective", Comparative Sociology, vol. 12, No. 2.

Graaf, N.D. and B. Steijn (1996), "The service class in a post-industrial society. Attitudes and behaviour of the social and cultural specialists in the public sector", paper presented at the 28th meeting of the International Sociological Association.

Güell, P. and T. Peters (eds.) (2012), La trama social de las prácticas culturales. Sociedad y subjetividad en el consumo cultural de los chilenos, Santiago, Ediciones Universidad Alberto Hurtado.

Güell, P., T. Peters and R. Morales (2012), "Derechos culturales y aseguramiento en el acceso al consumo cultural: aplicación empírica de una canasta básica de consumo cultural para Chile", La trama social de las prácticas culturales. Sociedad y subjetividad en el consumo cultural de los chilenos, P. Güell and T. Peters (eds.), Santiago, Ediciones Universidad Alberto Hurtado. 
Herring, C. (1989), Splitting the Middle. Political Alienation, Acquiescence, and Activism among America's Middle Layers, New York, Praeger.

Knowledge@Wharton (2008), “The New Global Middle Class: Potentially Profitable - But Also Unpredictable" [online] http:// knowledge.wharton.upenn.edu/article/the-new-global-middleclass-potentially-profitable-but-also-unpredictable/.

León, A. and J. Martínez (2004), "La estratificación social chilena hacia fines del siglo xx", Políticas Sociales series, No. 52 (LC/L.1584-P), Santiago, Economic Commission for Latin America and the Caribbean (ECLAC).

López-Calva, L.F. and E. Ortiz-Juárez (2012), "Clases medias y vulnerabilidad a la pobreza en América Latina", Pensamiento Iberoamericano, No. 10.

Lora, E. and J. Fajardo (2011), Latin American Middle Classes: The Distance between Perception and Reality, Washington, D.C., Inter-American Development Bank.

Lury, C. (2000), Consumer Culture, Cornwall, Polity Press.

Marx, C. and F. Engels (1971), Manifiesto del partido comunista, Beijing, Ediciones en Lenguas Extranjeras.

McAdams, J. (1987), "Testing the theory of the new class", The Sociological Quarterly, vol. 28, No. 1, Wiley.

Méndez, M.L. (2010), "Clases medias en Chile: transformaciones, sentido de pertenencia y tensiones entre proyectos de movilidad", Las clases medias en América Latina, R. Franco, M. Hopenhayn and A. León (coords.), Santiago, Mexico City, Siglo xxı/Economic Commission for Latin America and the Caribbean (ECLAC). (2008), "Middle class identities in a neoliberal age: tensions between contested authenticities", The Sociological Review, vol. 56, No. 2, Wiley.

(2007), "Do I See Myself as Others See Me? Middle Class Identities in Chile", thesis, Manchester, University of Manchester.

Méndez, M.L. and M. Gayo (2007), "El perfil de un debate: movilidad y meritocracia. Contribución al estudio de las sociedades latinoamericanas", Estratificación y movilidad social en América Latina. Transformaciones estructurales de un cuarto de siglo, R. Franco, A. León and R. Atria (coords.), Santiago, Lom Ediciones/Economic Commission for Latin America and the Caribbean (ECLAC).

Mills, C.W. (1959), White Collar. The American Middle Classes, New York, Oxford University Press.

Nazif, J.I. (2007), "Diferenciación social en patrones de consumo de exposiciones de arte, teatro, danza, recitales en vivo y circo en la sociedad chilena", Revista de Sociología, No. 21, Santiago, University of Chile.

Nivón, E. and D. Sánchez (2012), "Convergencias en México y Chile: entornos y estudios de consumo cultural", La trama social de las prácticas culturales. Sociedad y subjetividad en el consumo cultural de los chilenos, P. Güell and T. Peters, Santiago, Ediciones Alberto Hurtado University.
O'Dougherty, M. (2002), Consumption Intensified: The Politics of Middle-Class Daily Life in Brazil, Durham, Duke University Press.

OECD (Organization for Economic Cooperation and Development) (2011), Latin American Economic Outlook 2011. How MiddleClass is Latin America?, OECD Publishing.

OEI (Organization of Ibero-American States for Education, Science and Culture ) (2014), Encuesta Latinoamericana de hábitos y prácticas culturales 2013, Madrid.

Pakulski, J. and M. Waters (1996), The Death of Class, Thousand Oaks, SAGE

Paramio, L. and M. Güemes (2013), Cómo son y qué piensan los diferentes estratos de la clase media latinoamericana: caracterización y análisis de percepciones, Madrid, Instituto Universitario Ortega y Gasset.

Perkin, H. (1996), The Third Revolution. Professional Elites in the Modern World, London, Routledge.

(1989), The Rise of Professional Society. England since 1880, London, Routledge.

Peterson, R.A. and R.M. Kern (1996), "Changing highbrow taste: from snob to omnivore", American Sociological Review, vol. 61, No. 5, American Sociological Association.

Pinto, L. (2013), “Du bon usage de La Distinction”, Trente ans après La Distinction de Pierre Bourdieu, Ph. Coulangeon and J. Duval, Paris, La Découverte.

Rasse, A., R. Salcedo and J. Pardo (2009), "Transformaciones económicas y socioculturales: ¿cómo segmentar a los chilenos hoy?", El arte de clasificar a los chilenos. Enfoques sobre los modelos de estratificación en Chile, A. Joignant and P. Güell (coords.), Santiago, Ediciones Universidad Diego Portales.

Roberts, K. (2004), "Leisure inequalities, class divisions and social exclusion in present-day Britain", Cultural Trends, vol. 13, No. 2, Taylor \& Francis.

Savage, M. and others (1992), Property, Bureaucracy and Culture. Middle-Class Formation in Contemporary Britain, London, Routledge.

Skogen, K. (1996), "Young environmentalists: post-modern identities or middle-class culture?", The Sociological Review, vol. 44, No. 3, Wiley.

Torche, F. (2007), "Social status and cultural consumption: the case of reading in Chile", Poetics, vol. 35, No. 2-3, Amsterdam, Elsevier.

Torche, F. and L.F. López-Calva (2013), "Stability and vulnerability of the Latin American middleclass", Oxford Development Studies, vol. 41, No. 4, Taylor \& Francis.

UNDP (United Nations Development Programme) (2002), Desarrollo humano en Chile. Nosotros los chilenos: un desafio cultural 2002, Santiago.

Wahrman, D. (1995), Imagining the Middle Class. The Political Representation of Class in Britain, c.1780-1840, Cambridge, Cambridge University Press.

Wright, E.O. (1985), Classes, London, Verso. (1978), Class, Crisis and the State, London, New Left Books. 
ANNEX A1

Activities studied

TABLE A1.1

\section{Cultural practices analysed}

\begin{tabular}{|c|c|c|c|c|c|c|}
\hline \multirow{2}{*}{ Label } & \multirow{2}{*}{$\begin{array}{c}\text { Relative weight } \\
\text { (percentages) }\end{array}$} & \multirow{2}{*}{$\begin{array}{l}\text { Square distance } \\
\text { to the origin }\end{array}$} & \multicolumn{2}{|c|}{ Axis 1} & \multicolumn{2}{|c|}{ Axis 2} \\
\hline & & & Coordinates & Contributions & Coordinates & Contributions \\
\hline \multicolumn{7}{|l|}{ Exhibitions } \\
\hline $\begin{array}{l}\text { Painting } \\
\text { Photography } \\
\text { Other visual arts } \\
\text { No exhibitions }\end{array}$ & $\begin{array}{l}0.333 \\
0.135 \\
0.109 \\
2.280\end{array}$ & $\begin{array}{r}7.593 \\
20.091 \\
25.100 \\
0.253\end{array}$ & $\begin{array}{r}0.99 \\
1.00 \\
1.13 \\
-0.26\end{array}$ & $\begin{array}{l}1.86 \\
0.76 \\
0.79 \\
0.86\end{array}$ & $\begin{array}{r}-0.60 \\
-0.31 \\
0.07 \\
0.10\end{array}$ & $\begin{array}{l}1.76 \\
0.20 \\
0.01 \\
0.35\end{array}$ \\
\hline \multicolumn{7}{|l|}{ Theatre } \\
\hline $\begin{array}{l}\text { More than } 4 \text { times } \\
2 \text { or } 3 \text { times } \\
\text { Once } \\
\text { Has not been }\end{array}$ & $\begin{array}{l}0.111 \\
0.207 \\
0.165 \\
2.375\end{array}$ & $\begin{array}{r}24.778 \\
12.828 \\
16.328 \\
0.203\end{array}$ & $\begin{array}{r}1.42 \\
1.05 \\
0.58 \\
-0.20\end{array}$ & $\begin{array}{l}1.26 \\
1.30 \\
0.31 \\
0.53\end{array}$ & $\begin{array}{r}-0.63 \\
-0.77 \\
-0.22 \\
0.11\end{array}$ & $\begin{array}{l}0.64 \\
1.78 \\
0.11 \\
0.43\end{array}$ \\
\hline \multicolumn{7}{|l|}{ Dance } \\
\hline $\begin{array}{l}\text { Ballet and dance } \\
\text { Folk dance } \\
\text { Doesn't go to dance }\end{array}$ & $\begin{array}{l}0.132 \\
0.509 \\
2.152\end{array}$ & $\begin{array}{r}20.637 \\
4.613 \\
0.328\end{array}$ & $\begin{array}{r}1.11 \\
0.44 \\
-0.19\end{array}$ & $\begin{array}{l}0.93 \\
0.55 \\
0.46\end{array}$ & $\begin{array}{r}-0.73 \\
-0.05 \\
0.05\end{array}$ & $\begin{array}{l}1.03 \\
0.02 \\
0.07\end{array}$ \\
\hline \multicolumn{7}{|l|}{ Recitals } \\
\hline $\begin{array}{l}\text { Folk music } \\
\text { Rock music } \\
\text { Has not been to concerts }\end{array}$ & $\begin{array}{l}0.157 \\
0.265 \\
2.044\end{array}$ & $\begin{array}{r}17.236 \\
9.791 \\
0.398\end{array}$ & $\begin{array}{r}0.55 \\
1.03 \\
-0.26\end{array}$ & $\begin{array}{l}0.26 \\
1.60 \\
0.80\end{array}$ & $\begin{array}{r}-0.34 \\
-0.06 \\
0.04\end{array}$ & $\begin{array}{l}0.26 \\
0.01 \\
0.05\end{array}$ \\
\hline \multicolumn{7}{|l|}{ Pantomime } \\
\hline $\begin{array}{l}\text { Yes } \\
\text { No }\end{array}$ & $\begin{array}{l}0.263 \\
2.594\end{array}$ & $\begin{array}{l}9.847 \\
0.102\end{array}$ & $\begin{array}{r}1.28 \\
-0.13\end{array}$ & $\begin{array}{l}2.46 \\
0.25\end{array}$ & $\begin{array}{r}1.59 \\
-0.16\end{array}$ & $\begin{array}{l}9.80 \\
1.00\end{array}$ \\
\hline \multicolumn{7}{|l|}{ Juggling } \\
\hline $\begin{array}{l}\text { Yes } \\
\text { No }\end{array}$ & $\begin{array}{l}0.442 \\
2.415\end{array}$ & $\begin{array}{l}5.464 \\
0.183\end{array}$ & $\begin{array}{r}1.15 \\
-0.21\end{array}$ & $\begin{array}{l}3.32 \\
0.61\end{array}$ & $\begin{array}{r}1.20 \\
-0.22\end{array}$ & $\begin{array}{l}9.31 \\
1.70\end{array}$ \\
\hline \multicolumn{7}{|l|}{ Puppetry } \\
\hline $\begin{array}{l}\text { Yes } \\
\text { No }\end{array}$ & $\begin{array}{l}0.207 \\
2.650\end{array}$ & $\begin{array}{r}12.782 \\
0.078\end{array}$ & $\begin{array}{r}1.51 \\
-0.12\end{array}$ & $\begin{array}{l}2.69 \\
0.21\end{array}$ & $\begin{array}{r}1.59 \\
-0.12\end{array}$ & $\begin{array}{l}7.73 \\
0.61\end{array}$ \\
\hline \multicolumn{7}{|l|}{ Magic } \\
\hline \multicolumn{7}{|l|}{ Humour } \\
\hline $\begin{array}{l}\text { Yes } \\
\text { No }\end{array}$ & $\begin{array}{l}0.359 \\
2.499\end{array}$ & $\begin{array}{l}6.969 \\
0.143\end{array}$ & $\begin{array}{r}1.29 \\
-0.19\end{array}$ & $\begin{array}{l}3.39 \\
0.49\end{array}$ & $\begin{array}{r}1.31 \\
-0.19\end{array}$ & $\begin{array}{l}8.96 \\
1.29\end{array}$ \\
\hline \multicolumn{7}{|l|}{ Cinema } \\
\hline $\begin{array}{l}\text { More than } 7 \text { times } \\
\text { From } 4 \text { to } 6 \\
3 \text { times } \\
\text { Twice } \\
\text { Once } \\
\text { Has not been to cinema }\end{array}$ & $\begin{array}{l}0.140 \\
0.178 \\
0.183 \\
0.165 \\
0.138 \\
2.054\end{array}$ & $\begin{array}{r}19.471 \\
15.062 \\
14.640 \\
16.328 \\
19.673 \\
0.391\end{array}$ & $\begin{array}{r}1.45 \\
1.00 \\
0.76 \\
0.48 \\
0.42 \\
-0.32\end{array}$ & $\begin{array}{l}1.67 \\
1.02 \\
0.59 \\
0.22 \\
0.14 \\
1.19\end{array}$ & $\begin{array}{r}-0.56 \\
-0.43 \\
-0.17 \\
0.19 \\
-0.01 \\
0.08\end{array}$ & $\begin{array}{l}0.64 \\
0.49 \\
0.08 \\
0.09 \\
0.00 \\
0.18\end{array}$ \\
\hline \multicolumn{7}{|l|}{ Type of cinema } \\
\hline $\begin{array}{l}\text { Action } \\
\text { Comedy/humour } \\
\text { Drama } \\
\text { Romantic } \\
\text { Science fiction } \\
\text { Documentary } \\
\text { Children's } \\
\text { Suspense } \\
\text { Other type of cinema }\end{array}$ & $\begin{array}{l}0.844 \\
0.472 \\
0.153 \\
0.388 \\
0.200 \\
0.127 \\
0.118 \\
0.156 \\
0.278\end{array}$ & $\begin{array}{r}2.384 \\
5.052 \\
17.643 \\
6.365 \\
13.253 \\
21.452 \\
23.279 \\
17.316 \\
9.260\end{array}$ & $\begin{array}{r}-0.01 \\
0.01 \\
0.15 \\
-0.26 \\
0.39 \\
0.11 \\
0.25 \\
0.46 \\
-0.68\end{array}$ & $\begin{array}{l}0.00 \\
0.00 \\
0.02 \\
0.15 \\
0.18 \\
0.01 \\
0.04 \\
0.19 \\
0.73\end{array}$ & $\begin{array}{r}0.16 \\
-0.03 \\
-0.36 \\
0.00 \\
-0.01 \\
-0.62 \\
0.07 \\
0.31 \\
0.11\end{array}$ & $\begin{array}{l}0.31 \\
0.01 \\
0.30 \\
0.00 \\
0.00 \\
0.71 \\
0.01 \\
0.22 \\
0.05\end{array}$ \\
\hline
\end{tabular}


Table A1.1 (continued)

\begin{tabular}{|c|c|c|c|c|c|c|}
\hline \multirow{2}{*}{ Label } & \multirow{2}{*}{$\begin{array}{l}\text { Relative weight } \\
\text { (percentages) }\end{array}$} & \multirow{2}{*}{$\begin{array}{l}\text { Square distance } \\
\text { to the origin }\end{array}$} & \multicolumn{2}{|c|}{ Axis 1} & \multicolumn{2}{|c|}{ Axis 2} \\
\hline & & & Coordinates & Contributions & Coordinates & Contributions \\
\hline \multicolumn{7}{|l|}{ Frequency video } \\
\hline $\begin{array}{l}2 \text { or } 3 \text { DVDs a week } \\
1 \text { DVD a week } \\
1 \text { DVD a fortnight } \\
\text { DVD every } 1-3 \text { months } \\
\text { DVD almost never } \\
\text { Doesn't watch videos }\end{array}$ & $\begin{array}{l}0.595 \\
0.536 \\
0.305 \\
0.508 \\
0.166 \\
0.746\end{array}$ & $\begin{array}{r}3.800 \\
4.333 \\
8.363 \\
4.620 \\
16.185 \\
2.828\end{array}$ & $\begin{array}{r}0.54 \\
0.25 \\
0.17 \\
0.06 \\
-0.30 \\
-0.65\end{array}$ & $\begin{array}{l}0.97 \\
0.18 \\
0.05 \\
0.01 \\
0.08 \\
1.77\end{array}$ & $\begin{array}{r}0.13 \\
-0.01 \\
-0.05 \\
-0.13 \\
0.01 \\
0.00\end{array}$ & $\begin{array}{l}0.15 \\
0.00 \\
0.01 \\
0.12 \\
0.00 \\
0.00\end{array}$ \\
\hline \multicolumn{7}{|l|}{ Frequency books } \\
\hline $\begin{array}{l}\text { Books daily } \\
\text { Books every fortnight } \\
\text { Book every } 1-3 \text { months } \\
\text { Book once a year } \\
\text { Doesn't read books }\end{array}$ & $\begin{array}{l}0.398 \\
0.249 \\
0.272 \\
0.226 \\
1.711\end{array}$ & $\begin{array}{r}6.175 \\
10.473 \\
9.492 \\
11.616 \\
0.670\end{array}$ & $\begin{array}{r}0.58 \\
0.56 \\
0.80 \\
0.43 \\
-0.40\end{array}$ & $\begin{array}{l}0.77 \\
0.44 \\
0.99 \\
0.24 \\
1.56\end{array}$ & $\begin{array}{r}-0.83 \\
-0.43 \\
-0.29 \\
0.08 \\
0.29\end{array}$ & $\begin{array}{l}4.03 \\
0.66 \\
0.34 \\
0.02 \\
2.13\end{array}$ \\
\hline \multicolumn{7}{|l|}{ Type of books } \\
\hline $\begin{array}{l}\text { Novels } \\
\text { Short stories } \\
\text { Self-help } \\
\text { History and biography } \\
\text { Technology, science } \\
\text { Religious } \\
\text { Other } \\
\text { None, doesn't read }\end{array}$ & $\begin{array}{l}0.813 \\
0.272 \\
0.190 \\
0.213 \\
0.112 \\
0.207 \\
0.248 \\
0.597\end{array}$ & $\begin{array}{r}2.512 \\
9.519 \\
14.076 \\
12.428 \\
24.463 \\
12.828 \\
10.536 \\
3.789\end{array}$ & $\begin{array}{r}0.24 \\
0.09 \\
0.51 \\
0.28 \\
0.54 \\
-0.44 \\
-0.17 \\
-0.62\end{array}$ & $\begin{array}{l}0.26 \\
0.01 \\
0.28 \\
0.09 \\
0.19 \\
0.23 \\
0.04 \\
1.30\end{array}$ & $\begin{array}{r}-0.21 \\
0.22 \\
-0.42 \\
-0.25 \\
-0.32 \\
-0.32 \\
0.04 \\
0.56\end{array}$ & $\begin{array}{l}0.53 \\
0.20 \\
0.49 \\
0.19 \\
0.17 \\
0.32 \\
0.01 \\
2.77\end{array}$ \\
\hline \multicolumn{7}{|l|}{ Museums } \\
\hline $\begin{array}{l}\text { Art museums } \\
\text { Historical museums } \\
\text { Doesn't go to museums }\end{array}$ & $\begin{array}{l}0.120 \\
0.288 \\
2.285\end{array}$ & $\begin{array}{r}22.727 \\
8.919 \\
0.250\end{array}$ & $\begin{array}{r}1.46 \\
0.82 \\
-0.24\end{array}$ & $\begin{array}{l}1.46 \\
1.09 \\
0.72\end{array}$ & $\begin{array}{r}-0.74 \\
-0.12 \\
0.06\end{array}$ & $\begin{array}{l}0.97 \\
0.06 \\
0.12\end{array}$ \\
\hline \multicolumn{7}{|l|}{ Frequency TV } \\
\hline $\begin{array}{l}\text { Daily } \\
\text { Almost daily } \\
1 \text { to } 3 \text { days a week }\end{array}$ & $\begin{array}{l}2.286 \\
0.293 \\
0.228\end{array}$ & $\begin{array}{r}0.250 \\
8.757 \\
11.541\end{array}$ & $\begin{array}{r}-0.02 \\
0.14 \\
0.06\end{array}$ & $\begin{array}{l}0.01 \\
0.03 \\
0.00\end{array}$ & $\begin{array}{r}0.06 \\
-0.29 \\
-0.22\end{array}$ & $\begin{array}{l}0.14 \\
0.35 \\
0.15\end{array}$ \\
\hline \multicolumn{7}{|l|}{ Craftwork } \\
\hline $\begin{array}{l}\text { Yes } \\
\text { No }\end{array}$ & $\begin{array}{l}1.638 \\
1.219\end{array}$ & $\begin{array}{l}0.744 \\
1.343\end{array}$ & $\begin{array}{r}0.34 \\
-0.45\end{array}$ & $\begin{array}{l}1.05 \\
1.41\end{array}$ & $\begin{array}{r}-0.08 \\
0.11\end{array}$ & $\begin{array}{l}0.15 \\
0.20\end{array}$ \\
\hline \multicolumn{7}{|l|}{ Original paintings } \\
\hline $\begin{array}{l}\text { Yes } \\
\text { No }\end{array}$ & $\begin{array}{l}0.406 \\
2.451\end{array}$ & $\begin{array}{l}6.030 \\
0.166\end{array}$ & $\begin{array}{r}1.02 \\
-0.17\end{array}$ & $\begin{array}{l}2.42 \\
0.40\end{array}$ & $\begin{array}{r}-0.39 \\
0.06\end{array}$ & $\begin{array}{l}0.90 \\
0.15\end{array}$ \\
\hline \multicolumn{7}{|l|}{ Sculptures } \\
\hline $\begin{array}{l}\text { Yes } \\
\text { No }\end{array}$ & $\begin{array}{l}0.183 \\
2.674\end{array}$ & $\begin{array}{r}14.640 \\
0.068\end{array}$ & $\begin{array}{r}1.36 \\
-0.09\end{array}$ & $\begin{array}{l}1.92 \\
0.13\end{array}$ & $\begin{array}{r}-0.50 \\
0.03\end{array}$ & $\begin{array}{l}0.68 \\
0.05\end{array}$ \\
\hline \multicolumn{7}{|l|}{ Prints } \\
\hline $\begin{array}{l}\text { Yes } \\
\text { No }\end{array}$ & $\begin{array}{l}0.197 \\
2.660\end{array}$ & $\begin{array}{r}13.500 \\
0.074\end{array}$ & $\begin{array}{r}1.29 \\
-0.10\end{array}$ & $\begin{array}{l}1.87 \\
0.14\end{array}$ & $\begin{array}{r}-0.40 \\
0.03\end{array}$ & $\begin{array}{l}0.46 \\
0.03\end{array}$ \\
\hline \multicolumn{7}{|l|}{ Collector's books } \\
\hline $\begin{array}{l}\text { Yes } \\
\text { No }\end{array}$ & $\begin{array}{l}0.363 \\
2.495\end{array}$ & $\begin{array}{l}6.879 \\
0.145\end{array}$ & $\begin{array}{r}1.15 \\
-0.17\end{array}$ & $\begin{array}{l}2.71 \\
0.39\end{array}$ & $\begin{array}{r}-0.46 \\
0.07\end{array}$ & $\begin{array}{l}1.12 \\
0.16\end{array}$ \\
\hline \multicolumn{7}{|l|}{ Newspaper sections } \\
\hline $\begin{array}{l}\text { International news } \\
\text { Chilean reportage } \\
\text { Chilean politics } \\
\text { Chilean crime } \\
\text { Sport } \\
\text { Social pages } \\
\text { Reads all sections } \\
\text { Doesn't read newspapers }\end{array}$ & $\begin{array}{l}0.187 \\
0.289 \\
0.119 \\
0.259 \\
0.200 \\
0.124 \\
0.466 \\
0.863\end{array}$ & $\begin{array}{r}14.297 \\
8.896 \\
23.000 \\
10.048 \\
13.301 \\
22.072 \\
5.132 \\
2.309\end{array}$ & $\begin{array}{r}0.21 \\
0.15 \\
0.36 \\
0.07 \\
0.14 \\
0.14 \\
0.27 \\
-0.50\end{array}$ & $\begin{array}{l}0.05 \\
0.04 \\
0.09 \\
0.01 \\
0.02 \\
0.01 \\
0.19 \\
1.25\end{array}$ & $\begin{array}{r}-0.63 \\
-0.05 \\
-0.36 \\
0.18 \\
0.48 \\
0.31 \\
-0.24 \\
0.20\end{array}$ & $\begin{array}{l}1.07 \\
0.01 \\
0.22 \\
0.12 \\
0.68 \\
0.18 \\
0.40 \\
0.50\end{array}$ \\
\hline \multicolumn{7}{|l|}{ Radio programming } \\
\hline $\begin{array}{l}\text { Music } \\
\text { News } \\
\text { Opinion programmes } \\
\text { Doesn't listen to radio }\end{array}$ & $\begin{array}{l}1.808 \\
0.436 \\
0.135 \\
0.304\end{array}$ & $\begin{array}{r}0.581 \\
5.556 \\
20.198 \\
8.384\end{array}$ & $\begin{array}{r}0.01 \\
-0.11 \\
0.22 \\
0.07\end{array}$ & $\begin{array}{l}0.00 \\
0.03 \\
0.04 \\
0.01\end{array}$ & $\begin{array}{r}0.05 \\
-0.31 \\
0.01 \\
0.11\end{array}$ & $\begin{array}{l}0.06 \\
0.60 \\
0.00 \\
0.05\end{array}$ \\
\hline
\end{tabular}


Table A1.1 (concluded)

\begin{tabular}{|c|c|c|c|c|c|c|}
\hline \multirow{2}{*}{ Label } & \multirow{2}{*}{$\begin{array}{l}\text { Relative weight } \\
\text { (percentages) }\end{array}$} & \multirow{2}{*}{$\begin{array}{l}\text { Square distance } \\
\text { to the origin }\end{array}$} & \multicolumn{2}{|c|}{ Axis 1} & \multicolumn{2}{|c|}{ Axis 2} \\
\hline & & & Coordinates & Contributions & Coordinates & Contributions \\
\hline \multicolumn{7}{|l|}{ Type of magazines } \\
\hline Design and decoration & 0.129 & 21.213 & 0.43 & 0.14 & -0.48 & 0.44 \\
\hline Sport & 0.138 & 19.776 & 0.59 & 0.27 & 0.49 & 0.48 \\
\hline Current affairs (politics) & 0.187 & 14.241 & 0.71 & 0.54 & -0.74 & 1.52 \\
\hline General interest & 0.363 & 6.879 & 0.45 & 0.42 & 0.05 & 0.01 \\
\hline Doesn't read magazines & 1.608 & 0.777 & -0.40 & 1.48 & 0.15 & 0.52 \\
\hline \multicolumn{7}{|l|}{ Internet use } \\
\hline Internet communication & 0.694 & 3.118 & 0.54 & 1.16 & 0.03 & 0.01 \\
\hline Internet information searches & 0.436 & 5.556 & 0.54 & 0.72 & -0.46 & 1.33 \\
\hline Internet music downloading & 0.122 & 22.461 & 0.43 & 0.13 & 0.31 & 0.17 \\
\hline Other Internet & 0.193 & 13.809 & 0.62 & 0.42 & -0.05 & 0.01 \\
\hline Doesn't use Internet & 1.413 & 1.022 & -0.55 & 2.47 & 0.11 & 0.24 \\
\hline Has no books & 0.445 & 5.425 & -0.89 & 1.99 & 0.47 & 1.46 \\
\hline $1-10$ books & 0.838 & 2.409 & -0.34 & 0.55 & 0.13 & 0.20 \\
\hline $11-25$ books & 0.501 & 4.705 & 0.12 & 0.04 & 0.15 & 0.16 \\
\hline $26-50$ books & 0.459 & 5.224 & 0.34 & 0.31 & -0.25 & 0.42 \\
\hline $51-100$ books & 0.309 & 8.239 & 0.67 & 0.78 & -0.38 & 0.66 \\
\hline Over 100 books & 0.229 & 11.466 & 1.24 & 2.00 & -0.76 & 1.95 \\
\hline $\mathrm{dk} / \mathrm{da}$ books & 0.076 & 36.622 & -0.39 & 0.06 & 0.20 & 0.04 \\
\hline \multicolumn{7}{|l|}{ Travel abroad } \\
\hline Yes & 0.185 & 14.410 & 1.15 & 1.39 & -0.46 & 0.57 \\
\hline No & 2.672 & 0.069 & -0.08 & 0.10 & 0.03 & 0.04 \\
\hline \multicolumn{7}{|l|}{ Travel within Chile } \\
\hline Yes & 0.923 & 2.096 & 0.72 & 2.73 & 0.05 & 0.04 \\
\hline No & 1.934 & 0.477 & -0.34 & 1.30 & -0.02 & 0.02 \\
\hline \multicolumn{7}{|l|}{ Stadium outings } \\
\hline Yes & 0.373 & 6.662 & 0.63 & 0.85 & 0.48 & 1.27 \\
\hline Yes & 0.275 & 9.388 & 1.61 & 4.06 & -0.09 & 0.03 \\
\hline No & 2.582 & 0.107 & -0.17 & 0.43 & 0.01 & 0.00 \\
\hline \multicolumn{7}{|l|}{ Craft fairs } \\
\hline Yes & 0.762 & 2.749 & 0.79 & 2.70 & 0.13 & 0.17 \\
\hline No & 2.095 & 0.364 & -0.29 & 0.98 & -0.05 & 0.06 \\
\hline \multicolumn{7}{|l|}{ Lectures } \\
\hline Yes & 0.167 & 16.115 & 1.77 & 2.95 & -0.39 & 0.36 \\
\hline No & 2.690 & 0.062 & -0.11 & 0.18 & 0.02 & 0.02 \\
\hline \multicolumn{7}{|l|}{ Amusement parks } \\
\hline Yes & 0.372 & 6.676 & 1.10 & 2.53 & 0.79 & 3.43 \\
\hline No & 2.485 & 0.150 & -0.16 & 0.38 & -0.12 & 0.51 \\
\hline Zoo & & & & & & \\
\hline Yes & 0.178 & 15.062 & 1.41 & 2.02 & 0.84 & 1.84 \\
\hline No & 2.679 & 0.066 & -0.09 & 0.13 & -0.06 & 0.12 \\
\hline \multicolumn{7}{|l|}{ Sporting activities } \\
\hline Yes & 0.464 & 5.159 & 0.87 & 1.98 & 0.50 & 1.69 \\
\hline No & 2.393 & 0.194 & -0.17 & 0.38 & -0.10 & 0.33 \\
\hline
\end{tabular}

Source: Prepared by the authors, on the basis of data from the National Survey on Cultural Participation and Consumption. 
ANNEX A2

\section{Class categories}

TABLE A2.1

\section{Categorization of class categories used in the analysis}

\begin{tabular}{|c|c|c|}
\hline Activity or occupation & Frequency & Percentage \\
\hline High-level executives & 32 & 0.78 \\
\hline Professionals & 225 & 5.39 \\
\hline Engineering, health-care and other technicians & 56 & 1.33 \\
\hline Primary school teachers & 9 & 0.23 \\
\hline Other intermediate-level technicians and professionals & 120 & 2.88 \\
\hline Office workers & 109 & 2.61 \\
\hline Customer service staff & 58 & 1.38 \\
\hline Personal service workers & 142 & 3.40 \\
\hline Shop assistants & 269 & 6.45 \\
\hline Skilled agricultural and fisheries workers & 22 & 0.52 \\
\hline Extraction and construction industry workers & 148 & 3.55 \\
\hline Metal and mechanical industry workers & 91 & 2.17 \\
\hline Precision mechanics and artisans & 116 & 2.78 \\
\hline Machinery operators & 49 & 1.17 \\
\hline Drivers & 149 & 3.56 \\
\hline Unskilled sales and service workers & 174 & 4.17 \\
\hline Labourers in the primary and secondary sectors & 150 & 3.59 \\
\hline Employed s/o & 33 & 0.80 \\
\hline UNEMP-PRI-<250 & 29 & 0.69 \\
\hline UNEMP-SEC- $<250$ & 45 & 1.09 \\
\hline UNEMP-SEC-250 to 500 & 21 & 0.51 \\
\hline UNEMP-UNIHIGH-250 to 500 & 22 & 0.54 \\
\hline UNEMP-SEC-500 to $1 \mathrm{M}$ & 24 & 0.57 \\
\hline UNEMP-UNIHIGH-500 to $1 \mathrm{M}$ & 25 & 0.59 \\
\hline HOU-PRI-<250 & 193 & 4.62 \\
\hline HOU-SEC- $<250$ & 168 & 4.03 \\
\hline HOU-TECPR-<250 & 41 & 0.97 \\
\hline HOU-PRI-250 to 500 & 35 & 0.85 \\
\hline HOU-SEC-250 to 500 & 150 & 3.59 \\
\hline HOU-TECPR-250 to 500 & 28 & 0.68 \\
\hline HOU- HIGHPR -250 to 500 & 22 & 0.54 \\
\hline HOU-SEC-500 to $1 \mathrm{M}$ & 22 & 0.54 \\
\hline STU-SEC- $<250$ & 54 & 1.30 \\
\hline STU-SEC-250 to 500 & 64 & 1.54 \\
\hline STU-TECPR-250 to 500 & 22 & 0.52 \\
\hline STU-UNIHIGH-250 to 500 & 39 & 0.94 \\
\hline STU-SEC-500 to $1 \mathrm{M}$ & 31 & 0.75 \\
\hline STU-UNIHIGH-500 to $1 \mathrm{M}$ & 37 & 0.87 \\
\hline STU-UNIHIGH-+1M & 57 & 1.37 \\
\hline RET-PRI- $<250$ & 131 & 3.15 \\
\hline RET-SEC- $<250$ & 65 & 1.55 \\
\hline RET-PRI-250 to 500 & 26 & 0.62 \\
\hline RET-UNIHIGH-+1M & 30 & 0.73 \\
\hline OTHER-NON-EMP & 840 & 20.11 \\
\hline Total & 4176 & 100.00 \\
\hline
\end{tabular}

Source: Prepared by the authors, on the basis of data from the National Survey on Cultural Participation and Consumption.

Note: UNEMP: Unemployed; HOU: Housework; STU: Student; RET: Retired; OTHER-NON-EMP: Other non-employed; PRI: Primary education; SEC: Secondary education; UNIHIGH: University higher education; TECPR: Technical and professional education; HIGHPR: Higher professional education; <250: Household income below $\mathrm{Ch} \$ 250,000 ; 250$ to 500: Household income between Ch\$250,000 and Ch\$ 500,000; 500 to $1 \mathrm{M}$ : Household income between $\mathrm{Ch} \$ 500,000$ and $\mathrm{Ch} \$ 1 \mathrm{million} ;+1 \mathrm{M}$ : Household income over Ch\$ $1 \mathrm{million}$. 
TABLE A2.2

Types of cultural practice

\begin{tabular}{|c|c|c|}
\hline & Young & Adult \\
\hline Low status ${ }^{\mathrm{a}}$ & \multicolumn{2}{|c|}{ Little cultural participation } \\
\hline High status & $\begin{array}{l}\text { Youth culture } \\
\text { Highly active }\end{array}$ & $\begin{array}{l}\text { Elite culture } \\
\text { Highly active }\end{array}$ \\
\hline
\end{tabular}

Source: Prepared by the authors, on the basis of data from the National Survey on Cultural Participation and Consumption.

a By "status" here is only meant the accumulation of economic and educational resources.

FIGURE A2.1

\section{Social space of cultural practices and tastes}

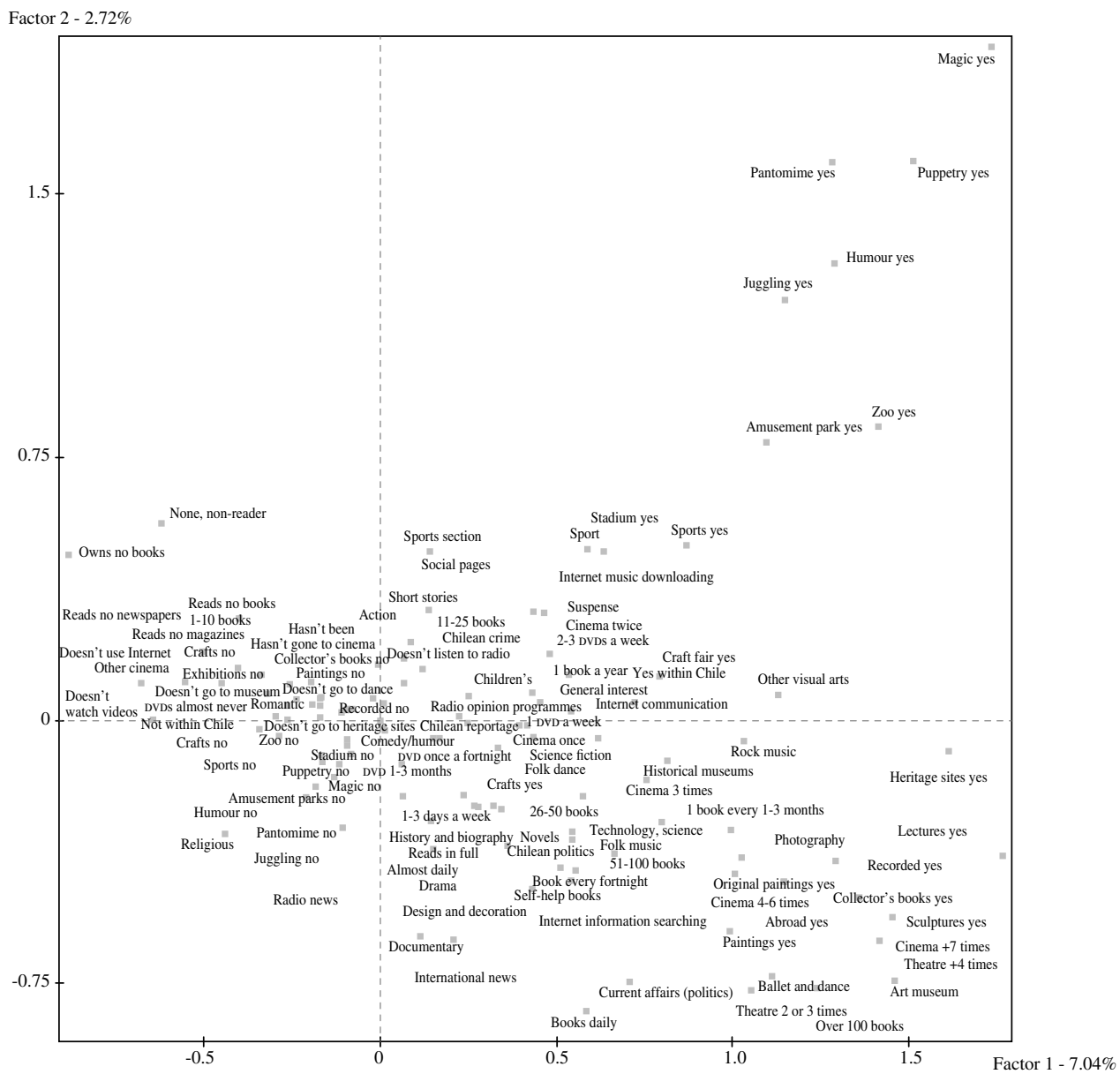

Source: Prepared by the authors, on the basis of data from the National Survey on Cultural Participation and Consumption. 
FIGURE A2.2

Sociodemographic variables that structure the sociocultural space (Trajectory lines for education level, socioeconomic group and age)

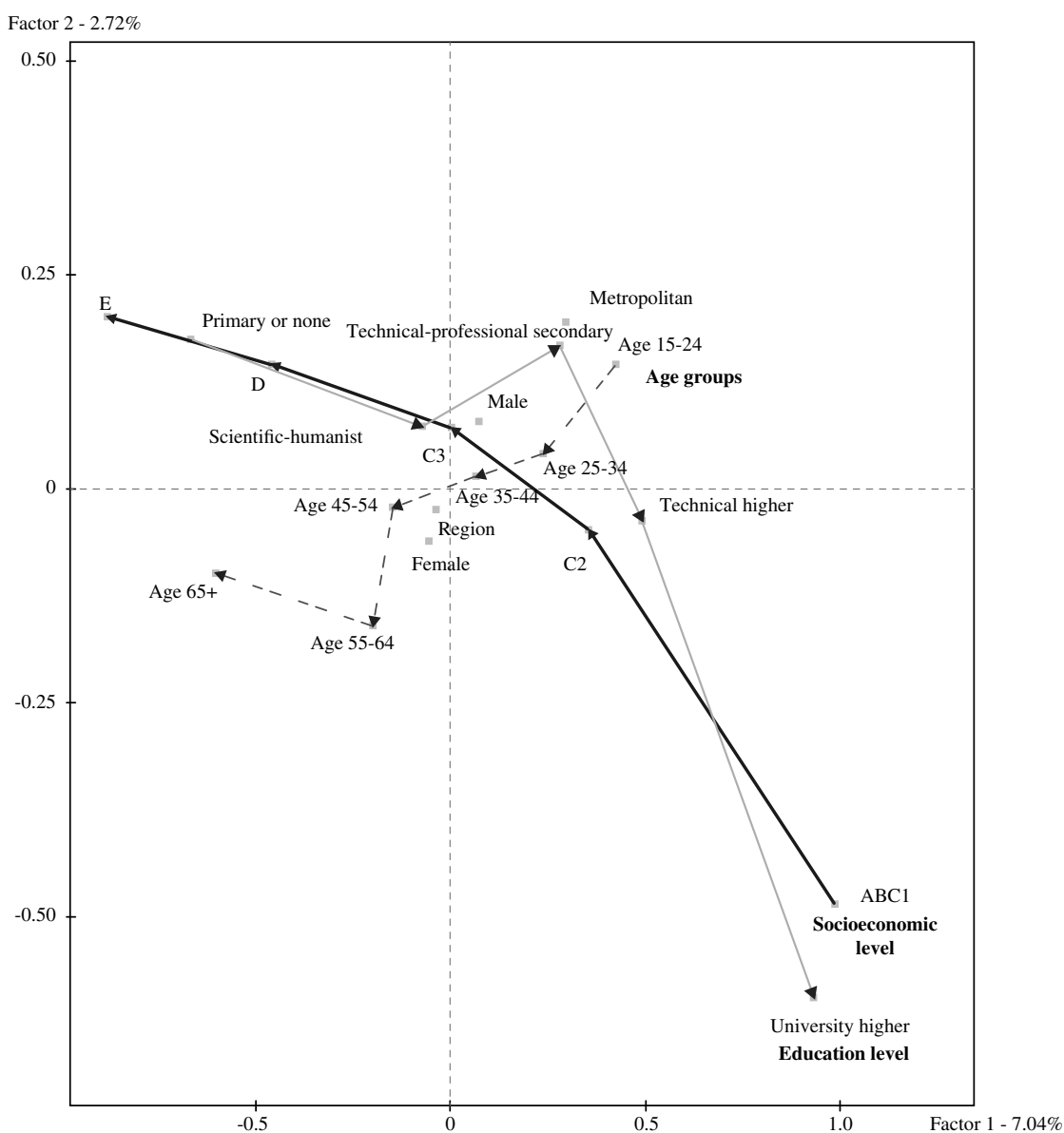

Source: Prepared by the authors, on the basis of data from the National Survey on Cultural Participation and Consumption. 
FIGURE A2.3

Spatial representation of the typology of cultural consumers

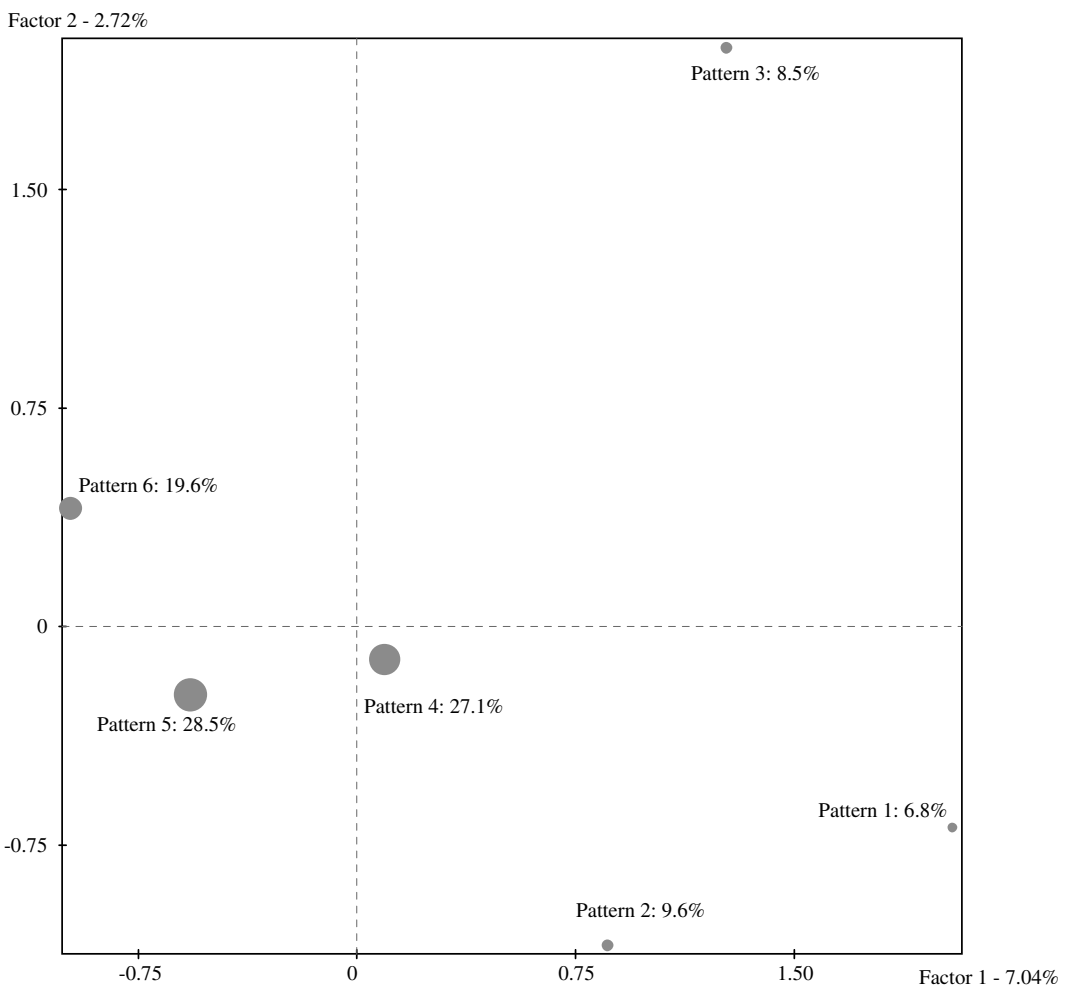

Source: Prepared by the authors, on the basis of data from the National Survey on Cultural Participation and Consumption. 
FIGURE A2.4

Variables structuring the sociocultural space: occupational dimension

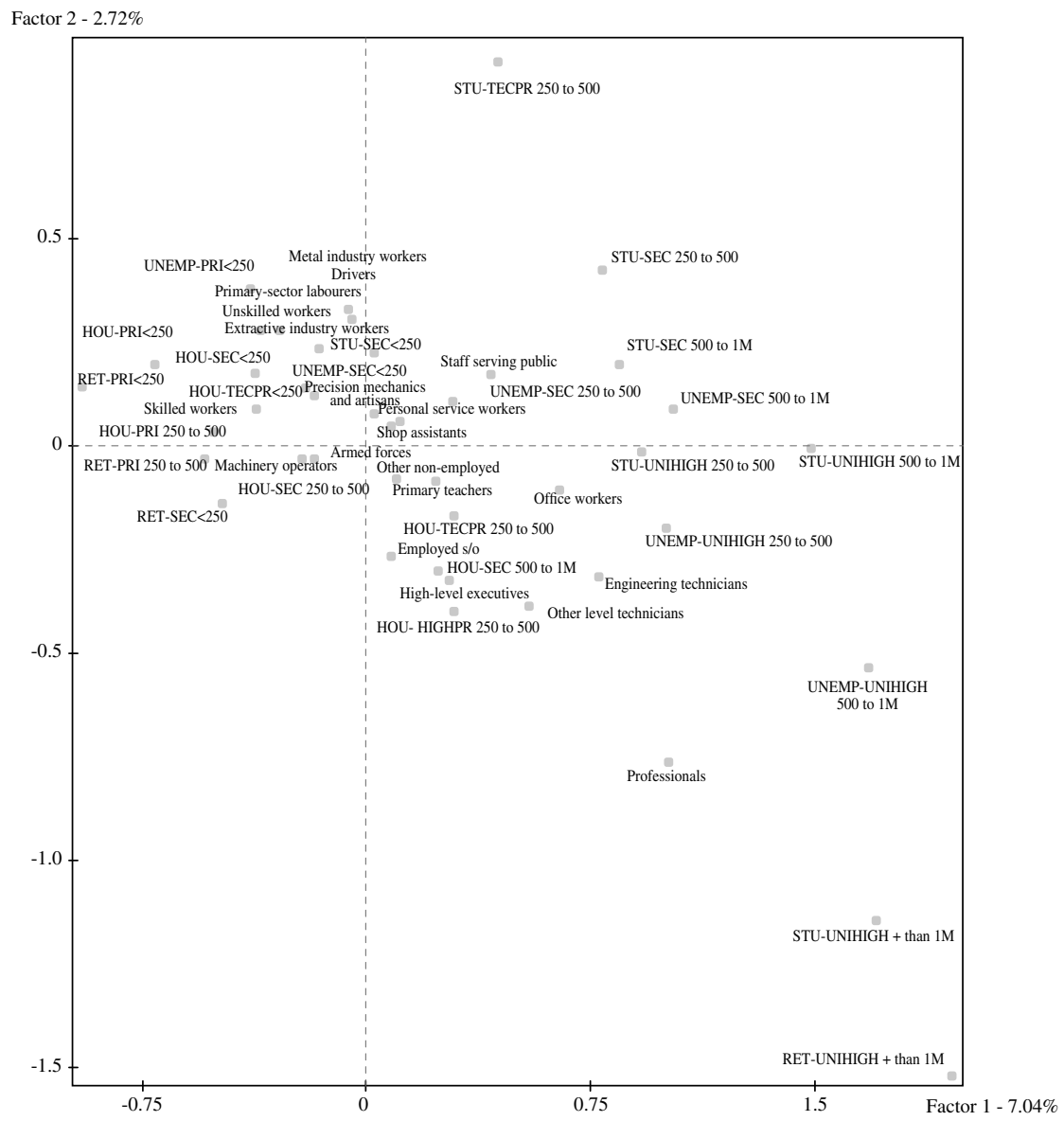

Source: Prepared by the authors, on the basis of data from the National Survey on Cultural Participation and Consumption.

Note: STU: Student; UNEMP: Unemployed; HOU: Housework; RET: Retired; PRI: Primary education; SEC: Secondary education; TECPR: Technical and professional education; UNIHIGH: University higher education; HIGHPR: Higher professional education; <250: Household income below $\mathrm{Ch} \$ 250,000 ; 250$ to 500: Household income between $\mathrm{Ch} \$ 250,000$ and $\mathrm{Ch} \$$ 500,000; 500 to $1 \mathrm{M}$ : Household income between Ch\$ 500,000 and Ch\$ 1 million; +1M: Household income over Ch\$ 1 million. 